\title{
Pemetaan Sosial Dampak Keberadaan Terminal BBM Pertamina di Kecamatan Camplong Sampang Madura
}

\author{
Dwi Budi Wiyanto ${ }^{1,2}$, Parmadi $^{3}$ \\ ${ }^{1}$ Fakultas Perikanan dan IImu Kelautan Universitas Udayana Bali \\ ${ }^{2}$ Mahasiswa Pasca Sarjana Universitas Brawijaya Malang \\ ${ }^{3}$ LSM Madura Development Watch Sampang \\ Email: wiyantomarine@gmail.com
}

Naskah diterima 12 Desember 2018, Revisi 15 Januari 2019, Terbit 20 April 2019

\begin{abstract}
Abstrak
DOI: http://dx.doi.org/10.21107/pmt.v12i1.5176

Manfaat yang dapat dirasakan oleh perusahaan melalui kegiatan tanggung jawab perusahaan sebagai upaya pengembangan masyarakat adalah terciptanya hubungan yang baik dengan stakeholder dan membina hubungan baik dengan masyarakat sehingga tidak pernah terjadi konflik. Pemetaan sosial (social mapping) merupakan upaya mengidentifikasi dan memahami struktur sosial (sistem kelembagaan dan individu) tata hubungan antar lembaga dan atau individu pada lingkungan sosial tertentu. Pelaksanaan kegiatan Social Mapping ini dilakukan di wilayah yang termasuk Ring 1 wilayah operasional PT Pertamina TBBM tepatnya di Kecamatan Camplong Kabupaten Sampang. Tujuan dari kegiatan ini adalah mengidentifikasi kebutuhan dasar masyarakat dan mengidentifikasi potensi sumberdaya serta modal sosial masyarakat yang berada di wilayah operasional PT Pertamina TBBM Camplong. Keberadaan suatu perusahaan di dalam suatu wilayah tertentu akan membawa dampak positif maupun dampak negative bagi lingkungan sekitar wilayah operasional perusahaan tersebut. Secara umum, responden memberikan persepsi positif akan keberadaan dan manfaat beroperasinya PT Pertamina TBBM Camplong. Salah satu indikasinya adalah timbulnya persepsi masyarakat di tiga desa yang menyatakan bahwa beroperasinya PT Pertamina TBBM Camplong membawa dampak peningkatan perekonomian desa.
\end{abstract}

Kata kunci : social mapping, PT Pertamina, Camplong, persepsi masyarakat

\section{PENDAHULUAN}

Keberadaan dan pengoperasian suatu perusahaan sangat penting untuk meningkatkan perekonomian dan kesejahteraan masyarakat di sekitarnya. Manfaat beroperasinya perusahaan di suatu wilayah dapat memberikan dorongan bagi perekonomian regional dalam bentuk penciptaan lapangan kerja, pembukaan jenis usaha baru, peningkatan PAD (Pendapatan Asli Daerah) dan berbagai kontriobusi positif lainnya. Sehingga secara langsung dapat dijelaskan bahwa keberadaan perusahaan harus bisa memberikan manfaat kepada masyarakat dan lingkungannya. Hal ini tidak bisa lepas dari hubungan dimana perusahaan bisa hidup dan berkembang karena ditopang oleh adanya kelompok masyarakat dan sebaliknya (Soekanto, 2007).

Namun tidak dapat dipungkiri bahwa tanpa pengelolaan yang baik, operasional perusahaan rentan terhadap potensi munculnya konflik sosial antar masyarakat di sekitarnya. Contoh dari potensi tersebut antara lain adalah masuknya tenaga kerja dari luar daerah, benturan budaya, masalah lingkungan dan masalah social lainnya. Hal tersebut tentu saja berpotensi untuk mengganggu operasional perusahaan yang pada akhirnya membawa dampak negatif terhadap keberlanjutan usaha. Masyarakat memiliki cara pandang tersendiri mengenai perusahaan. Cara masyarakat sekitar memandang perusahaan tersebut dapat diartikan sebagai persepsi. Menurut Soekanto (2007), paradigma perusahaan yang hanya berorientasi memperoleh laba (profit) sebesar-besarnya sudah mulai bergeser dan mulai berupaya memberikan dampak positif keberadaannya bagi kesejahteraan masyarakat sekitar.

Beberapa manfaat yang dapat dirasakan oleh perusahaan melalui 
kegiatan tanggung jawab perusahaan sebagai upaya pengembangan masyarakat adalah terciptanya hubungan yang baik dengan stakeholder (dalam hal ini masyarakat) dan membina hubungan baik dengan masyarakat sehingga tidak pernah terjadi konflik. Upaya perusahaan untuk menjalin hubungan dengan masyarakat lainnya adalah melalui komunikasi publik perusahaan. Menurut Chambers (2004) hubungan perusahaan dengan komunitas merupakan suatu tindakan yang harus dilakukan perusahaan untuk memelihara dan membina hubungan dengan lingkungan nya melalui komunikasi yang saling menguntungkan. Sejauh mana upaya perusahaan tersebut dapat mempengaruhi persepsi masyarakat sekitar terhadap aktivitas perusahaan merupakan hal perlu menjadi perhatian.

Untuk mengetahui berbagai kontribusi positif yang dapat diberikan dan potensi permasalahan yang mungkin terjadi terkait dengan operasional perusahaan perlu dilakukan sebuah kajian yang detail dan mendalam. Data dan informasi tersebut penting untuk mengetahui secara lebih jelas tentang berbagai permasalahan dan kebutuhan yang berkenaan dengan permasalahan masyarakat, sehingga perusahaan membantu menanganinya sebagai bentuk tanggung jawab sosial. Aktivitas untuk pengumpulan data dan informasi yang dimaksud dapat dilakukan melalui kegiatan Social Mapping.

Pemetaan sosial (social mapping) merupakan upaya mengidentifikasi dan memahami struktur sosial (sistem kelembagaan dan individu) tata hubungan antar lembaga dan atau individu pada lingkungan sosial tertentu. Pemetaan sosial dapat juga diartikan sebagai social profiling atau "pembuatan profil suatu masyarakat". Identifikasi kelembagaan dan individu ini dilakukan secara akademik melalui suatu penelitian secara langsung, menetapkan tata hubungan antara satu dengan lain dalam kawasan komunitas yang diteliti. Kegiatan ini sangat penting dilakukan oleh perusahaan karena setiap komunitas masyarakat akan memiliki kondisi dan permasalahan yang spesifik dan berbeda-beda. Social mapping berguna untuk mengetahui keadaan masyarakat di sekitar lokasi operasional perusahaan yang selanjutnya dapat dilanjutkan dengan analisa kebutuhan (need assessment) untuk mencari tahu kebutuhan masyarakat agar dapat direalisasikan.

Kegiatan Social Mapping memiliki kelebihan karena dapat mengetahui kondisi lingkungan sosial masyarakat dengan menggunakan data dan indikator yang jelas. Selain itu, hasil dari kegiatan Social Mapping dapat digunakan sebagai baseline data (acuan informasi) untuk menyusun perencanaan program yang lebih komprehensif dan seuai dengan kebutuhan masyarakat.

PT Pertamina merupakan salah satu Badan Usaha Milik Negara (BUMN) yang bergerak dibidang Energi dan Gas memiliki visi untuk menjadi perusahaan kelas dunia. Untuk mencapai hal tersebut adalah melalui kepatuhan terhadap peraturan yang berlaku, khususnya yang berkaitan dengan peraturan lingkungan hidup dan tanggung jawab sosial (CSR). Oleh karena itu PT Pertamina sangat memerlukan data dan informasi terkait kondisi sosial di sekitar wilayah operasional perusahaan. Data dan informasi tersebut yang dikumpulkan melalui kegiatan Social Mapping selanjutnya akan sangat berguna untuk menjadi acuan dalam penyusunan program CSR. Selain itu, data yang dikumpulkan melalui Social Mapping dapat digunakan oleh PT Pertamina dalam upaya melaksanakan penilaian PROPER (Program Penilaian Peringkat Kinerja Perusahaan dalam Pengelolaan Lingkungan Hidup) yang rutin dilakukan oleh Dinas Lingkungan Hidup Provinsi Jawa Timur.

Pelaksanaan kegiatan Social Mapping dilakukan di wilayah yang termasuk Ring 1 wilayah operasional PT Pertamina tepatnya di Kecamatan Camplong Kabupaten Sampang. Pemilihan lokasi ini didasarkan pada prakiraan besarnya dampak dan manfaat keberadaan perusahaan yang mempengaruhi lingkungan sekitarnya. Secara umum kegiatan Social Mapping dilaksanakan melalui serangkaian pengumpulan data primer dan sekunder, wawancara 
mendalam (in-depht interview) dan FGD (Focus Group Discussion).

Secara umum, tujuan pelaksanaan kegiatan Social Mapping ini adalah untuk mendapatkan data dan informasi yang lengkap terkait dengan kondisi sosial masyarakat di lingkungan sekitar wilayah operasional PT Pertamina. Secara lebih detail, tujuan dari kegiatan ini adalah :

1. Mengidentifikasi kebutuhan dasar masyarakat.

2. Mengidentifikasi potensi sumberdaya dan modal sosial masyarakat.

3. Mengidentifikasi tingkat dan jenis permasalahan, kerawanan sosial dan kriminalitas masyarakat.

4. Mengidentifikasi stake holders yang terkait langsung dan tidak langsung dengan kegiatan operasional perusahaan.

\section{METODOLOGI}

Metode Social Mapping cukup beragam dan hal yang cukup penting adalah kemampuan fasilitator untuk menjalankan metode tersebut. Pada dasarnya metode Social Mapping yang dilaksanakan harus di sesuaikan dengan :

a. Tujuan yang ingin di capai dari Social Mapping oleh perusahaan/institusi terkait. Hal ini paling penting dengan menentukan prioritas terlebih dahulu data-data yang ingin di dapatkan, dengan demikian kita dapat memiliki metode yang tepat untuk mendapatkan data itu dan tidak perlu membuangbuang tenaga, biaya dan waktu untuk data-data lain yang kurang menjadi prioritas.

b. Kondisi sosial masyarakat, dimana dengan melihat kondisi masyarakat sebelumnya dapat menentukan metode Social Mapping yang tepat dan efisien.

c. Sumber daya dan waktu yang tersedia dalam menjalankan Social Mapping

Data yang diperlukan dalam penyusunan kajian ini adalah data primer dan data sekunder yang dikumpulkan dari level perusahaan, dan level instansi terkait, serta data dari level masyarakat desa.

\section{- Pengumpulan Data Sekunder}

Data sekunder rentang waktu (time series) diambil dari berbagai sumber yang relevan. Data time series ini hanya bisa diperoleh dengan dukungan data sekunder yang lengkap dalam rentang waktu tertentu. Tabel dibawah ini menyajikan data dan informasi yang dibutuhkan serta sumber data yang relevan dalam rangka pelaksanaan studi pemetaan sosial.

Tabel 1. Data Sekunder

\begin{tabular}{|c|l|l|}
\hline No & \multicolumn{1}{|c|}{$\begin{array}{c}\text { Data Yang } \\
\text { Dibutuhkan }\end{array}$} & \multicolumn{1}{c|}{ Sumber Data } \\
\hline 1. & $\begin{array}{l}\text { Monografi } \\
\text { Kabupaten Sampang }\end{array}$ & $\begin{array}{l}\text { BPS } \\
\text { Kecamatan } \\
\text { Camplong }\end{array}$ \\
\hline 3. & $\begin{array}{l}\text { Monografi Desa } \\
\text { Lokasi }\end{array}$ & Kecamatan \\
\hline 4. & $\begin{array}{l}\text { Data kegiatan CSR } \\
\text { Perusahaan }\end{array}$ & $\begin{array}{l}\text { PT Pertamina dan } \\
\text { perusahaan lain di } \\
\text { sekitar wilayah } \\
\text { operasi pertamina } \\
\text { TBBM Camplong }\end{array}$ \\
\hline 5. & $\begin{array}{l}\text { Informasi kasus } \\
\text { kriminalitas, } \\
\text { kerawanan dan } \\
\text { konflik/ masalah } \\
\text { sosial }\end{array}$ & $\begin{array}{l}\text { Polres/ Polsek } \\
\text { setempat, Kantor } \\
\text { Kecamatan dan } \\
\text { Desa }\end{array}$ \\
\hline 6. & $\begin{array}{l}\text { Data kerentanan } \\
\text { kemiskinan/ kondisi } \\
\text { kesehatan/ } \\
\text { kesejahteraan/ } \\
\text { ekonomi }\end{array}$ & $\begin{array}{l}\text { Dinas Sosial, } \\
\text { Dinas Kesehatan, } \\
\text { BPS }\end{array}$ \\
\hline
\end{tabular}

\section{- Pengumpulan Data Primer}

Pengumpulan data dilapangan akan menggunakan Mixed Methods yaitu gabungan metode kuantitatif dan kualitatif. Mixed Methods menurut Creswell (2002) akan mengacu kepada konteks di mana peneliti mengumpulkan dan menganalisa data secara terintegrasi, baik data kualitatif maupun kuantitatif dalam suatu studi. Penggunaan Mixed Methods sesungguhnya bertujuan untuk saling menguatkan temuan dan analisa data yang dilakukan oleh peneliti,baik yang menggunakan metode kuantitatif dan kualitatif. Selain keunggulan Mixed Methods menurut Creswell (2002) adalah sifatnya yang cenderung practical akan lebih bervariasi dalam menjelaskan suatu fenomena sosial.

\section{Analisa Data}

Data sekunder maupun data primer yang dikumpulkan dianalisa dengan perpaduan antara metode kuantitatif dan kualitatif. Hasil analisa digunakan untuk 
menjelaskan hasil studi yang ditemukan serta menggambarkan berbagai fakta dan hubungan antar variabel yang di temukan dalam proses yang ada di lapangan. Hasil analisis tersebut mencakup :

1. Analisis kebutuhan dasar masyarakat sekitar perusahaan.

2. Analisis permasalahan masyarakat (kriminalitas, konflik dan kerawanan sosial).

3. Analisis potensi sumber daya dan modal sosial masyarakat.

4. Analisis staholder sekitar perusahaan, dan

5. Analisis potensi konflik dan cara penyelesaiannya.

\section{HASIL DAN PEMBAHASAN}

\section{- Karakteristik Masyarakat}

Pemetaan sosial (Social Mapping) dilakukan dengan bertujuan untuk mengetahui gambaran mengenai kondisi sosial, budaya dan perekonomian masyarakat di sebuah lokasi. Untuk melakukannya diperlukan kegiatan pengkajian, memantau dan mengumpulkan informasi tentang komunitas masyarakat yang berada di lokasi penelitian. Terkait dengan keberadaan PT. Pertamina TBBM Camplong, studi tentang sosial mapping sangat bermanfaat untuk mengetahui persepsi atau tanggapan masyarakat terhadap keberadaan dan operasional perusahaan di wilayah tersebut.

Masyarakat Madura termasuk di Kecamatan Camplong dikenal memiliki budaya yang khas, unik, stereotipikal, dan stigmatik. Penggunaan istilah khas menunjuk pada pengertian bahwa entitas etnik Madura memiliki kekhususan-kultural yang tidak serupa dengan etnografi komunitas etnik lain. Kekhususan kultural itu tampak antara lain pada ketaatan, ketundukan, dan kepasrahan mereka secara hierarkis kepada empat figur utama dalam berkehidupan, lebih-lebih dalam praksis keberagamaan. Keempat figur itu adalah Buppa,' Babbu, Guru, ban Rato (Ayah, Ibu, Guru, dan Pemimpin pemerintahan). Kepada figur-figur utama itulah kepatuhan hierarkis orang-orang Madura menampakkan wujudnya dalam praksis kehidupan sosial budaya mereka.
Bagi entitas etnik Madura, kepatuhan hierarkis tersebut menjadi keniscayaan untuk diaktualisasikan dalam praksis keseharian sebagai "aturan normatif" yang mengikat. Oleh karenanya, pengabaian atau pelanggaran yang dilakukan secara sengaja atas aturan itu menyebabkan pelakunya dikenakan sanksi sosial maupun kultural. Pemaknaan etnografis demikian berwujud lebih lanjut pada ketiadaan kesempatan dan ruang yang cukup untuk mengenyampingkan aturan normatif itu. Dalam makna yang lebih luas dapat dinyatakan bahwa aktualisasi kepatuhan itu dilakukan sepanjang hidupnya. Tidak ada kosa kata yang tepat untuk menyebut istilah lainnya kecuali ketundukan, ketaatan, dan kepasrahan kepada keempat figur tersebut.

Kepatuhan atau ketaatan kepada Ayah dan Ibu (buppa' ban Babbu') sebagai orangtua kandung atau nasabiyah sudah jelas, tegas, dan diakui keniscayaannya. Secara kultural, ketaatan dan ketundukan seseorang kepada kedua orangtuanya adalah mutlak. Jika tidak, ucapan atau sebutan kedurhakanlah ditimpakan kepadanya oleh lingkungan sosiokultural masyarakatnya. Bahkan, dalam konteks budaya mana pun kepatuhan anak kepada kedua orangtuanya juga menjadi kemestian secara mutlak, tidak dapat dinegosiasikan, maupun diganggu gugat. Yang mungkin berbeda, hanyalah cara dan bentuk dalam memanifestasikannya. Kepatuhan mutlak itu tidak terkendala oleh apa pun, sebagai kelaziman yang ditopang oleh faktor genealogis. Konsekuensi lanjutannya relatif dapat dipastikan bahwa jika pada saat ini seseorang (anak) patuh kepada orangtuanya maka pada saatnya nanti dia ketika menjadi orangtua akan ditaati pula oleh anakanaknya. Itulah salah satu bentuk pewarisan nilai-nilai kultural yang terdiseminasi. Siklus secara kontinu dan sinambung itu kiranya akan berulang dan berkelanjutan dalam kondisi normal, wajar, dan alamiah, kecuali kalau pewarisan nilai-nilai kepatuhan itu mengalami keterputusan yang disebabkan oleh berbagai kondisi, faktor, atau peristiwa luar biasa.

Kepatuhan orang-orang Madura kepada figur guru berposisi pada level 
hierarkis selanjutnya. Penggunaan dan penyebutan istilah guru menunjuk dan menekankan pada pengertian Kiaipengasuh pondok pesantren atau sekurangkurangnya Ustadz pada "sekolah-sekolah" keagamaan. Peran dan fungsi guru lebih ditekankan pada konteks moralitas yang dipertalikan dengan kehidupan eskatologis - terutama dalam aspek ketenteraman dan penyelamatan diri dari beban atau derita di dalam kehidupan akhirat (morality and sacred world). Oleh karena itu, ketaatan orangorang Madura kepada figur guru menjadi penanda khas budaya mereka yang - mungkin - tidak perlu diragukan lagi keabsahannya.

Siklus-generatif tentang kepatuhan orang Madura (sebagai murid) kepada figur guru ternyata tidak dengan sendirinya dapat terwujud sebagaimana ketaatan anak kepada figur I dan II, ayah dan ibunya. Kondisi itu terjadi karena tidak semua orang Madura mempunyai kesempatan untuk menjadi figur guru. Kendati pun terdapat anggapan-prediktif bahwa figur guru sangat mungkin diraih oleh murid karena aspek genealogis namun dalam realitasnya tidak dapat dipastikan bahwa setiap murid akan menjadi guru, mengikuti jejak orangtuanya. Oleh karenanya, makna kultural yang dapat ditangkap adalah bahwa bagi orang Madura belum cukup tersedia ruang dan kesempatan yang leluasa untuk mengubah statusnya menjadi orang yang senantiasa harus berperilaku patuh, tunduk, dan pasrah. Kepatuhan orang Madura kepada figur Rato (pemimpin pemerintahan) menempati posisi hierarkis keempat. Figur Rato dicapai oleh seseorang - dari mana pun etnik asalnya - bukan karena faktor genealogis melainkan karena keberhasilan prestasi dalam meraih status.

Nilai-nilai ketokohan dan kekuasaan secara dominan mampu menngerakkan masyarakat. Hal ini terjadi di 3 desa yang menjadi lokasi Social Mapping yaitu Desa Tambaan, Desa Banjar Talela dan Desa Dharma Camplong yang menunjukkan bahwa sosok Kepala Desa yang merupakan kepala pemerintahan adalah tokoh yang paling besar pengaruh dan peranannya bagi masyarakat. Selain itu terdapat pula tokoh-tokoh agama (ulama) yang merupakan pimpinan pondok pesantren yang dianggap sebagai sesepuh dan pembimbing spiritual masyarakat desa juga dianggap sebagai tokoh yang memiliki peran dan pengaruh yang kuat bagi masyarakat. Selanjutnya terdapat pula tokoh-tokoh pemuda dan pimpinan kelompok masyarakat (kelompok tani dan nelayan) juga dianggap sebagai tokoh dengan pengaruh yang kuat meskipun peranannya tidak sekuat Kepala Desa dan Ulama.

Hasil penelusuran data melalui pengamatan dan wawancara dengan warga menggambarkan bahwa karakteristik masyarakat Desa Tambaan, Desa Banjar Talela dan Desa Dharma Camplong dari sisi pekerjaan/ profesi relatif beragam (heterogen). Jenis pekerjaan masyarakat lokasi Social Mapping antara lain adalah petani, peternak, nelayan, pedagang, PNS dan sebagainya. Namun apabila ditinjau dari prosentase, maka profesi petani dan nelayan adalah karakteristik yang lebih dominan.

Karakteristik masyarakat nelayan berbeda dengan karakteristik masyarakat petani karena perbedaan sumberdaya yang dimilki. Masyarakat petani (agraris) menghadapi sumberdaya yang terkontrol yakni lahan untuk memproduksi suatu jenis komoditas dengan hasil yang dapat dipridiksi. Dengan sifat yang demikian memungkinkannya lokasi produksi yang menetap, sehingga mobilitas usaha yang relatif rendah dan faktor resiko relatif kecil (Stefanus, 2005).

Tohir (2001), mengemukakan bahwa terdapat fenomena yang menarik mengenai melimpahnya sumberdaya alam laut dengan masih rendahnya minat masyarakat nelayan untuk mengeksplorasi kekayaan laut. Fenomena ini jika dicermati secara mendalam, maka sebenarnya terdapat fakta bahwa masyarakat pesisir yang bermata pencaharian sebagai nelayan maupun melakukan aktivitas hidup di laut jumlahnya relatif kecil dibandingkan dengan yang bekerja sebagai petani di sawah, ladang dan sektor jasa. Hal ini berarti jenis mata pencaharian 
masyarakat nelayan heterogen dan warga masyarakat yang memilih sebagai nelayan pada dasarnya merupakan kelompok kecil saja. Dilihat dari tingkat kesejahteraan hidup nelayan rata-rata masih belum menggembirakan, karena sebagai nelayan kecil mereka menghadapi berbagai keterbatasan.

Dari perspektif antropologis, masyarakat nelayan berbeda dari masyarakat lainnya, seperti petani, buruh di kota atau masyarakat di daratan tinggi. Perspektif antropologis ini didasarkan pada realitas sosial, bahwa masyarakat nelayan memiliki pola kebudayaan yang berbeda dari masyarakat lain sebagai hasil interaksi mereka dengan lingkungan beserta sumberdaya yang ada didalamnya. Pola-pola kebudayaan ini menjadi kerangka berfikir atau referensi perilaku masyarakat nelayan dalam kehidupan sehari-harinya.

Meskipun terdapat perbedaan karakteristik antara masyarakat nelayan dan petani namun nilai-nilai gotong royong, sosial dan keagamaan dalam masyarakat tetap terpelihara dengan baik dan berjalan secara harmonis. Untuk menjaga spiritualisme didalam masyarakat, maka di lokasi Social Mapping ditemui beberapa kelompok pengajian yang dibentuk oleh warga. Tujuan dibentuknya kelompok-kelompok pengajian tersebut adalah dalam rangka untuk memperkuat nilai-nilai keagamaan dan kebersamaan dalam berinteraksi secara sosial sehingga memudahkan pembicaraan dan penyelesaian masalah yang terjadi.

Kultur masyarakat modern juga tercermin dalam kehidupan masyarakat di Desa Tambaan, Desa Banjar Talela dan Desa Dharma Camplong. Masyarakat di desa-desa ini sangat terbuka terhadap perubahan. Hal ini dapat dilihat dari sebagian besar masyarakat yang menerima adanya perkembangan pembangunan yang pesat di desa. Masyarakat berpendapat bahwa dengan adanya perkembangan kondisi lingkungan maka akan berpengaruh positif dan berpotensi meningkatkan taraf hidup masyarakat. Namun terdapat satu hal yang perlu diperhatikan, yaitu adanya kesan belum meratanya perkembangan desa, artinya bahwa hanya sebagian kelompok masyarakat saja yang merasakan dampak positif pembangunan dan perkembangan desa. Untuk mengatasi hal tersebut perlu adanya pendekatan secara kelembagaan agar hasil pembangunan dapat dirasakan oleh mayoritas warga desa (Sanoff, 2011).

Berdasarkan hasil pemetaan sosial, setidaknya terdapat 3 kelompok tokoh masyarakat yang dapat ditemui di lokasi

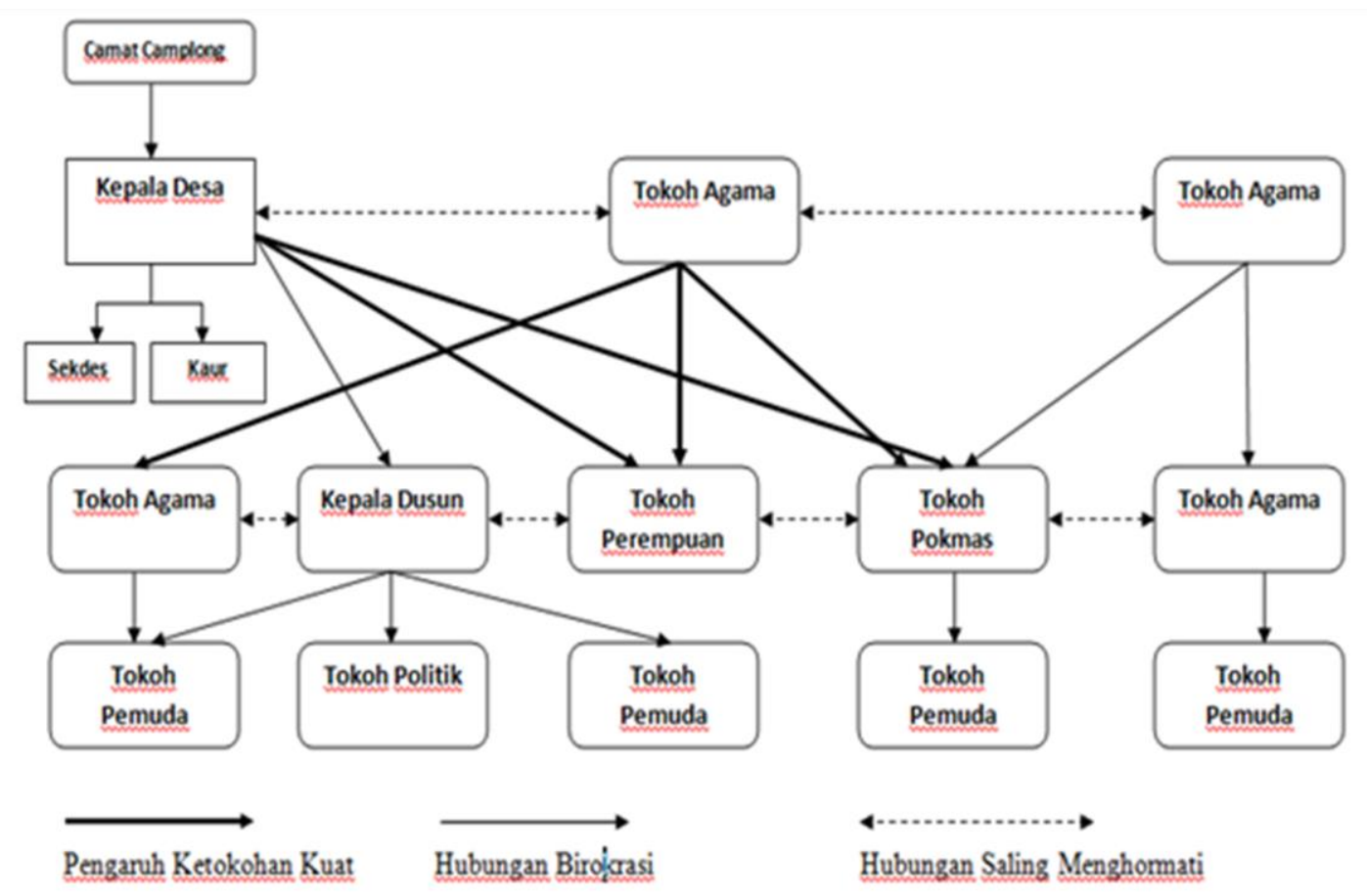

Gambar 1. Struktur Hierarkhi Hubungan Sosial Masyarakat di Lokasi Pemetaan Sosial 
penelitian, yaitu (1) kelompok pemerintahan desa,(2) kelompok ulama, (3) kelompok pemuda dan perkumpulan masyarakat. Secara umum struktur Hierarkhi hubungan antar kelompokkelompok tersebut disajikan pada Gambar 1.

Dalam menjalankan roda pemerintahan desa, Kepala Desa dibantu oleh beberapa lembaga. Berdasarkan hasil penelusuran data dan keterangan dari warga masyarakat, peranan lembagalembaga di Desa Tambaan, Desa Banjar Talela dan Desa Dharma Camplong berfungsi dengan baik. Hal ini dapat terjadi karena tupoksi dari masing-masing lembaga berjalan dengan baik sesuai peranannya masing-masing. Secara umum, lembaga desa yang berfungsi membantu tugas Kepala Desa adalah Sekdes, Bendahara Desa, BPD, Linmas Desa, Tenaga Medis dan sebagainya.

Gambar 1 diatas menunjukkan bahwa kalangan ulama adalah tokoh masyarakat yang merupakan patron bagi warga desa. Dari garis-garis hubungan aktor terlihat bahwa selain dengan Kepala Desa dan aparatnya yang merupakan pemegang kendali pemerintahan, semua kelompok dan individu berhubungan dengan ulama yang merupakan tokoh yang memberikan pengaruh kuat terhadap masyarakat desa. Aktor-aktor (Kepala Desa dan Ulama) tersebut membangun jaringan dengan hubungan saling menghormati dan saling menghargai dapat dilihat bahwa Kepala Desa membangun jaringan dengan ulama serta dengan kelompok tokoh dibawahnya, akan tetapi antar jaringan tersebut terdapat pula hubungan keterkaitan yang saling menghargai.

Kelompok yang terdapat di selain kelompok formal seperti Koperasi Desa, Kelompok Tani, Kelompok Nelayan dan lainnya, juga terdapat kelompok non formal seperti kelompok pengajian dan pemuda yang merupakan kelompokkelompok yang didirikan di hampir tiap dusun. Kelompok-kelompok tersebut merupakan modal sosial bagi desa, dan kelompok-kelompok tersebut membangun hubungan dengan perangkat desa, tokoh masyarakat ( tokoh agama, tokoh pemuda dan tokoh masyarakat lainnya). Melalui pertemuan-pertemuan rutin yang diadakan oleh kelompok-kelompok tersebut dapat memudahkan akses informasi, pembahasan program desa dan musyawarah permasalahan desa. Tokoh pemuda di desa juga membangun jaringan dengan tokoh agama dan tokoh masyarakat, jaringan yang dibangun tersebut diharapkan untuk memperkecil konflik yang biasa terjadi antara golongan muda dan golongan tua, yang disebabkan adanya perbedaan cara berfikir dan menyingkapi permasalahan. Jaringan yang di bangun dengan tokoh-tokoh agama dan tokoh masyarakat lainnya memudahkan koordinasi dan posisinya dihargai oleh masyarakat. Hubungan tersebut merupakan hubungan menghormati dan menghargai, serta hubungan ketokohan dan pengaruh yang kuat.Untuk kelompok formal khusus perempuan tidak ada, tetapi untuk nonformal terdapat kelompok pengajian. Tokoh perempuan dianggap bisa mengkoordinasikan program-program pemeberdayaan perempuan, serta mampu membangun jaringan dengan Kepala desa dan perangkat desa. Melalui tokoh perempuan pelaksanaan program yang berkaitan dengan pemberdayaan perempaun dapat diimplementasikan, selain itu permasalahan yang terjadi di desa melalui aktor ini dapat di musyawarahkan.

Terdapat tokoh lain dan bagi sebagian warga juga mempunyai pengaruh yang kuat, seperti pemilik sejumlah perahu dan kapal nelayan. Banyak nelayan yang bergantung kepada actor tersebut, terutama untuk kebutuhan perahu. Terdapat kelompok formal seperti paguyuban nelayan, karena mayoritas masyarakat desa adalah nelayan. Kelompok ini membangun jaringan dengan pemilik kapal dan perahu nelayan, hubungan antara kelompok tersebut yang saling menghormati dan menghargai.

Tokoh agama memiliki pengaruh yang kuat di dalam tatanan masyarakat desa dapat membangun jaringan dengan tokoh agama lainnya, tokoh masyarakat, tokoh pemuda dan kelompok-kelompok masyarakat lainnya. Karena kemampuan dalam pengusaaan bidang agama Islam, maka tokoh ulama mempunyai pengaruh 
yang kuat dalam masyarakat selain Kepala Desa.

Terdapat tokoh politik yang membangun jaringan dengan tokoh-tokoh agama dan masyarakat, serta kelompokkelompok dalam masyarakat, dan berkepentingan tinggi karena untuk keperluan posisi politiknya. Meskipun demikian untuk kekuatan pengaruhnya terhadap masyarakat masih belum mempunyai kekuatan yang tinggi, karena masyarakat masih lebih berpanutan pada tokoh agama dan kepala desa. Pengendalian masyarakat untuk berkoordinasi dengan kepala desa dan tokoh masyarakat lainnya merupakan tradisi atau adat di lokasi pemetaan sosial. Kepala sekolah mempunyai jaringan dengan Kepala Desa untuk berkoordinasi berkaitan dengan bidang pendidikan. Memajukan masyarakat desa bidang pendidikan memerlukan perhatian yang tinggi, Untuk itu perlu tokoh yang dapat membuka mata masyarakat tentang pentingnya pendidikan, baik pendidikan agama, karakter dan ilmu pengetahuan.

Tokoh perempuan yang ditemui di lokasi pemetaan sosial diwadahi oleh organisasi PKK ataupun pengajian muslimah. Tokoh wanita ini membangun jaringan dengan Kepala Desa, tokoh agama mauoun tokoh pemuda dengan tujuan untuk mengkoordinasikan pelaksaan program-program yang terkait dengan pemberdayaan perempuan di wilayah desa. Tokok perempuan dianggap mempunyai kekuatan tinggi dalam mempengaruhi masyarakat terutama untuk kelompok perempuan. Kelompok ini sering memberikan ide dan inovasi untuk pengembangan dan memajukan desa.

Penyampaian informasi dan komunikasi dari aparatur desa kepada masyarakat dilakukan secara formal dengan mengadakan pertemuan/ musyawarah warga dibalai desa ayau kediaman Kepala Desa. Waktu dan frekuensi pertemuan tidak terlalu rutin dan disesuaikan dengan acara atau agenda yang akan dilaksanakan. Terdapat pula jalur komunikasi dan penyampaian informasi secara non-formal melalui acara pengajian/ kegiatan keagamaan yang ada dalam lingkungan desa, baik pengajian umum dan pengajian yang di bentuk oleh masyarakat sendiri sebagai kegiatan rutin. Jika ada yang perlu di musyawarahkan dengan desa, Kepala Desa dengan aparat melaksanakan rapat desa untuk menampung usulan masyarakat dan kesepakatan yang akan dijadikan acuan dan petunjuk pelaksaan di lapangan.

Posisi Kepala Desa perlu menjadi prioritas pendekatan dan perhatian untuk mendukung pelaksanaan programprogram CSR yang dilakukan oleh perusahaan. Selain itu pendekatan kepada tokoh agama/ulama yang mempunyai derajat kepentingan dan derajat kekuatan yang tinggi juga perlu dilakukan mengingat figur ini merupakan panutan dan masyarakat dan akan sangat membantu pelaksanaan program dan menyelesikan permasalahan di desa. Selanjutnya peran Kepala Desa sangat dibutuhkan untuk ikut merencanakan, mengimplementasikan dan memfasilitasi program-program yang akan dilakukan perusahaan terkait dengan program CSR.

\section{- Tanggapan Masyarakat Terhadap PT Pertamina TBBM Camplong}

Pada dasarnya, masyarakat di desa lokasi pemetaan sosial sudah sangat mengenal dan mengetahui tentang PT. Pertamina TBBM Camplong dan keberadaannya, serta lokasi industrinya yang sudah memuai operasionalnya sejak tahun 1987. Hal ini menunjukkan bahwa masyarakat sangat familiar dengan keberadaan industri tersebut serta telah terjadi interaksi antara keduanya. Tidak sedikit masyarakat yang telah menerima dan merasakan manfaat dari beroperasinya perusahaan ini.

Keberadaan PT. Pertamina TBBM Camplong dalam pekembangannya tentu membawa dampak positif dan negatif bagi lingkungan sekitar. Dampak positif yang sudah dirasakan masyarakat sekitar wilayah operasi antara lain adalah adanya bantuan berupa sembako, saranaprasarana desa, bantuan sarana pendukung nelayan, khitanan masal, beasiswa, santunan anak yatim, pelatihanpelatihan, peluang kerja di perusahaan tersebut dan lain sebagainya. 
Tabel 2. Hasil Identifikasi Respon Masyarakat terhadap Keberadaan dan Operasional PT.Pertamina TBBM Camplong

\begin{tabular}{|c|c|c|c|}
\hline No & Pernyataan & $\%$ (Prosentase) & Jenis Respon \\
\hline 1 & Desa Tambaan & & \\
\hline a. & Menciptakan lapangan kerja & $75 \%$ & Positif \\
\hline b. & Menciptakan lapangan usaha (warung, kost-kostan, dll) & $64 \%$ & Positif \\
\hline c. & Ketersediaan BBM lancar & $75 \%$ & Positif \\
\hline d. & $\begin{array}{l}\text { Adanya program CSR dari Pertamina untuk masyarakat } \\
\text { Desa Tambaan }\end{array}$ & $83 \%$ & Positif \\
\hline e. & $\begin{array}{l}\text { Kesempatan warga untuk bekerja di Pertamina sangat } \\
\text { terbatas }\end{array}$ & $74 \%$ & Negatif \\
\hline f. & Kurangnya pemanfaatan tenaga kerja lokal & $68 \%$ & Negatif \\
\hline $\mathrm{q}$. & Timbulnya bau gas saat pembongkaran dari kapal & $31 \%$ & Negatif \\
\hline $\mathrm{h}$. & $\begin{array}{l}\text { Kurangnya kedekatan perusahaan dan pekerjanya } \\
\text { dengan masyarakat }\end{array}$ & $25 \%$ & Negatif \\
\hline 2 & Desa Banjar Talela & & \\
\hline a. & Menciptakan lapangan kerja & $73 \%$ & Positif \\
\hline b. & $\begin{array}{l}\text { Sebagian warga desa dapat bekerja di Pertamina } \\
\text { (sebagai supir dan cleaning service) }\end{array}$ & $75 \%$ & Positif \\
\hline C. & Warga mudah mendapatkan BBM & $85 \%$ & Positif \\
\hline d. & $\begin{array}{l}\text { Hubungan/ interaksi antara Pertamina dengan Desa } \\
\text { (melalui kepala desa) belum terjalin dengan baik }\end{array}$ & $63 \%$ & Negatif \\
\hline e. & $\begin{array}{l}\text { Lalu lintas agak terhambat karena adanya mobil Tanki } \\
\text { Pertamina yang mengangkut BBM }\end{array}$ & $53 \%$ & Negatif \\
\hline f. & Kadang tercium bau gas di sekitar lokasi Pertamina & $47 \%$ & Negatif \\
\hline g. & $\begin{array}{l}\text { Belum ada program CSR yang diberikan Pertamina } \\
\text { kepada warga Desa Banjar Talela }\end{array}$ & $54 \%$ & Negatif \\
\hline 3 & Desa Dharma Camplong & & \\
\hline a. & $\begin{array}{l}\text { BBM mudah didapatkan oleh warga karena keberadaan } \\
\text { Pertamina }\end{array}$ & $87 \%$ & Positif \\
\hline b. & $\begin{array}{l}\text { Perekonomian warga meningkat dengan adanya aktivitas } \\
\text { Pertamina }\end{array}$ & $79 \%$ & Positif \\
\hline C. & $\begin{array}{l}\text { Bisa menciptakan lapangan kerja dan usaha bagi } \\
\text { masyarakat secara umum }\end{array}$ & $85 \%$ & Positif \\
\hline d. & $\begin{array}{l}\text { Belum ada program CSR yang diberikan Pertamina } \\
\text { kepada warga Desa Dharma Camplong }\end{array}$ & $80 \%$ & Negatif \\
\hline e. & $\begin{array}{l}\text { Kurangnya kesempatan kerja yang diberikan oleh } \\
\text { Pertamina kepada warga sekitar }\end{array}$ & $65 \%$ & Negatif \\
\hline f. & $\begin{array}{l}\text { Minimya respon Pertamina terhadap proposal kegiatan } \\
\text { yang diajukan oleh warga Desa Dharma Camplong }\end{array}$ & $70 \%$ & Negatif \\
\hline g. & $\begin{array}{l}\text { Adanya jalur pipa Pertamina di pesisir utara sampai } \\
\text { dengan selatan Desa yang tidak diberi pelampung } \\
\text { sehingga membuat jarring nelayan sering tersangkut }\end{array}$ & $53 \%$ & Negatif \\
\hline
\end{tabular}

Berdasar hasil FGD dan wawancara mendalam yang dilakukan kepada masyarakat dan tokoh masyarakat desa sebanyak 150 responden yang terdiri dari berbagai unsur, maka dapat terindentifikasi respon terhadap keberadaan dan operasional termasuk daftar kebutuhan masyarakat yang diusulkan sebagai program kepada PT. Pertamina TBBM Camplong.
Keberadaan suatu perusahaan di dalam suatu wilayah tertentu akan membawa dampak positif maupun damapk negative bagi lingkungan sekitar wilayah operasional perusahaan tersebut. Sehingga perlu interaksi yang baik antara perusahaan dengan warga masyarakat sekitar untuk menjaga eksistensi (keberadaan) dan mendukung kegiatan perusahaan dalam jangka panjang, 
tujuannya agar keberadaan perusahaan dapat diterima oleh masyarakat.

Berdasarkan hasil pengolahan kusioner dan wawancara yang di lakukan terhadap 150 responden terkait dengan keberadaan PT Pertamina TBBM Camplong, dapat dijelaskan bahwa hampir seluruh responden (97.5\%) mengetahui akan keberadaan dan operasional perusahaan. Hal ini menunjukkan bahwa keberadaan dan operasional PT Pertamina TBBM Camplong telah diterima dalam kehidupan sehari-hari warga masyarakat di lokasi pemetaan social.

Secara umum, responden memberikan persepsi positif akan keberadaan dan manfaat beroperasinya PT Pertamina TBBM Camplong. Salah satu indikasinya adalah timbulnya persepsi masyarakat di tiga desa yang menyatakan bahwa beroperasinya PT Pertamina TBBM Camplong membawa dampak peningkatan perekonomian desa. Dengan beroperasinya PT Pertamina TBBM Camplong, maka dapat menyerap tenaga kerja local. Persepsi ini diberikan lebih dari $70 \%$ responden yang diwawancarai. Walaupun begitu, namun terdapat pula responden yang berpendapat bahwa proporsi tenaga kerja yang direkrut dari warga local masih sedikit, sehingga perlu ada kesempatan yang lebih luas bagi warga sekitar untuk menjadi pekerja di PT Pertamina TBBM Camplong. Adapun jenis pekerjaan yang dapat dijalani oleh warga antara lain adalah driver (sopir), security (keamanan), cleaning service (petugas kebersihan) atau posisi kerja lainnya yang tidak membutuhkan keahlian khusus. Proporsi warga yang menyatakan hal ini cukup besar yaitu sekitar $50 \%-60 \%$ dari responden. Hal tersebut pernah dibahas dalam forum FGD di lokasi desa, bahwa rekruitmen pekerja di PT Pertamina TBBM Camplong harus mengikuti instruksi dan terkoordinasi dengan Kantor Pusat Pertamina yang berkedudukan di Surabaya. Selanjutnya, PT Pertamina memiliki kualifikasi dan standarisasi khusus dalam merekrut pekerja. Selain itu, tidak setiap saat PT Pertamina TBBM Camplong membuka kesempatan/ lowongan pekerjaan. Hal-hal tersebut diatas merupakan penjelasan tentang mekanisme penerimaan pekerja oleh PT
Pertamina TBBM Camplong. Indikasi lain yang didapatkan dari hasil kuisioner tentang dampak positif keberadaan PT Pertamina TBBM Camplong adalah wilayah desa yang menjadi ramai sehingga memberikan pemasukan kepada warga yang memiliki kost-kostan, warung makan atau toko yang melayani kebutuhan pekerja PT Pertamina TBBM Camplong. Keberadaan PT Pertamina TBBM Camplong yang cukup besar manfaatnya bagi masyarakat adalah bahwa BBM di Kecamatan Camplong selalu tersedia dan tidak pernah kekurangan. Hal ini bisa dianggap wajar, mengingat distribusi BBM merupakan salah satu tugas pokok yang dimiliki oleh PT Pertamina TBBM Camplong.

Dampak positif berikutnya yang dirasakan oleh warga adalah adanya Program CSR/ Community Development oleh PT Pertamina TBBM Camplong yang diterima warga masyarakat (respon > $71 \%$ ). Namun berdasarkan penelusuran informasi lebih lanjut, dari ketiga desa yang menjadi lokasi pemetaan social, program CSR PT Pertamina TBBM Camplong hanya diberikan kepada Desa Tambaan yang merupakan wilayah Ring 1 untuk pelaksanaan CSR. Pada satu sisi, pemberian program CSR bagi warga Desa Tambaan tentu saja akan memberikan dampak positif bagi perusahaan, namun bagi warga Desa Banjar Talela dan Dharma Camplong hal itu memberikan kesan yang negatif (respon 60-65\%).

Selanjutnya dari aspek lingkungan, tidak ditemukan persepsi warga masyarakat yang menyebutkan adannya kerusakan atau pencemaran lingkungan akibat operasional PT Pertamina TBBM Camplong. Namun satu hal yang perlu diperhatikan oleh PT Pertamina TBBM Camplong adalah kadang-kadang tercium bau gas yang cukup menyengat pada saat terjadi bongkar muat BBM/Gas di pelabuhan Pertamina. Untuk meminimalisir gangguan seperti itu, maka PT Pertamina TBBM Camplong perlu menemukan atau menggunakan metode baru agar masalah bau gas tersebut dapat segera diatasi.

Interaksi antara PT Pertamina TBBM Camplong dengan warga masyarakat juga dapat diketahui dari hasil kuisioner. Warga 
masyarakat di Desa Tambaan berpendapat bahwa PT Pertamina TBBM Camplong telah memiliki hubungan/ interaksi sosial yang baik dengan masyarakat. Hal ini ditunjukkan oleh hubungan baik yang terjalin antara PT Pertamina TBBM Camplong dengan pihak Kepala Desa Tambaan. Namun bagi 2 desa lainnya, hubungan interaksi tersebut masih dirasakan kurang (respon > 67.5\%). Menurut hasil kuisioner dan wawancara, seringkali proposal kegiatan yang dikirim oleh Desa kepada PT Pertamina TBBM Camplong tidak mendapatkan tanggapan (respon 60\%-70\%). Oleh karena itu, perlu adanya diaharapkan dari PT Pertamina TBBM Camplong bisa memberikan respon yang lebih baik terhadap proposal kegiatan yang dikirim oleh warga.

Hasil analisis pada umumnya menunjukkan bahwa program CSR/Community Development terasa sangat nyata dalam memenuhi aspirasi masyarakat yang menjadi responden dalam studi ini. Mayoritas responden mengatakan keberadaan PT Pertamina TBBM Camplong dan program CSR nya sangat membantu masyarakat nyata dan diterima dengan baik serta mendapatkan respon positif dari masyarakat.

\section{- Pemetaan Kebutuhan Masyarakat}

Pemetaan kebutuhan masyarakat di sekitar lokasi operasional perusahaan merupakan upaya perumusan kebutuhan masyarakat yang dapat ditangani dalam program Community Development perusahaan. Jadi tujuan dari pemetaan kebutuhan masyarakat ini adalah diketahuinya kebutuhan masyarakat sekitar wilayah operasional terhadap keberadaan perusahaan PT. PERTAMINA TBBM Camplong di Kabupaten Sampang.

Oleh karena itu, untuk mengetahui kebutuhan masyarakat secara nyata dilapangan, maka perlu dilakukan suatu studi atau kajian yang mendalam dan menyeluruh, studi kebutuhan ini biasanya disebut dengan pemetaan kebutuhan. Pemetaan kebutuhan dibutuhkan dalam rangka mengetahui tingkat kebutuhan masyarakat sebagai akibat dari keberadaan suatu perusahaan di lingkungan masyarakat tersebut.
Hasil pemetaan kebutuhan masyarakat menunjukkan bahwa usulan kebutuhan masyarakat sangat banyak dan variatif. Untuk lebih fokus pada kebutuhan yang lebih penting maka dilakukan identifikasi ulang untuk menemukan kebutuhan prioritas masyarakat melalui Focus Group Discussion (FGD) yang dilaksanakan di masing-masing Desa dengan jumlah peserta sebanyak kurang lebih 30 orang. Peserta terdiri dari unsur pemerintah desa, tokoh agama, tokoh pemuda, tokoh kelompok petani dan tokoh kelompok nelayan. Maka dapat teridentifikasi beberapa usulan kebutuhan program kegiatan pemberdayaan masyarakat desa yang menjadi prioritas.

Tabel 3. Usulan Melalui FGD

\begin{tabular}{|c|c|c|}
\hline No & $\begin{array}{c}\text { Desa } \\
\text { Pengusul }\end{array}$ & Usulan Program \\
\hline 1 & $\begin{array}{l}\text { Desa } \\
\text { Tambaan }\end{array}$ & $\begin{array}{l}\text { a. Pembuatan } \\
\text { drainase di Daluran } \\
\text { Tambas Desa Tambaan. } \\
\text { b. Pengerasan jalan di } \\
\text { Dusun Tambas sebelah } \\
\text { timur Pertamina } \\
\text { c. Program pengentasan } \\
\text { Buta Akasara } \\
\text { d. Pelatihan kewirausahaan } \\
\text { bagi para pemuda dan } \\
\text { Karang Taruna Desa } \\
\text { Tambaan air } \\
\text { e. Pengadaan sarana air } \\
\text { bersih } \\
\text { f. Perbaikan sarana sekolah } \\
\text { g. Bantuan alat-alat } \\
\text { pertanian } \\
\text { h. Pengobatan massal }\end{array}$ \\
\hline 2 & $\begin{array}{l}\text { Desa } \\
\text { Banjar } \\
\text { Talela }\end{array}$ & 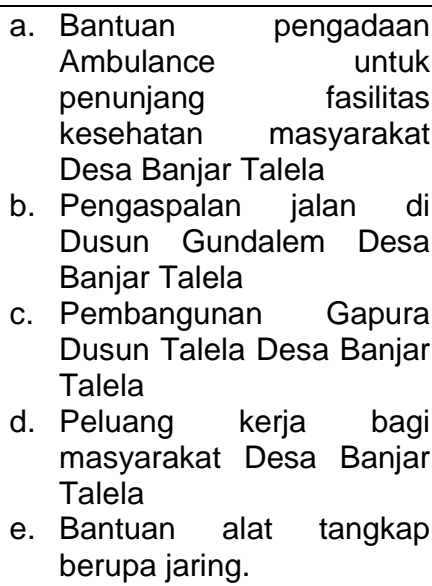 \\
\hline 3 & $\begin{array}{l}\text { Desa } \\
\text { Dharma } \\
\text { Camplong }\end{array}$ & $\begin{array}{l}\text { a. Bantuan alat tangkap } \\
\text { (jaring) untuk nelayan } \\
\text { Pesisir Desa Dharma } \\
\text { Camplong } \\
\text { b. Tandon Air untuk } \\
\text { pengairan sawah di Desa } \\
\text { Dharma Camplong }\end{array}$ \\
\hline
\end{tabular}




\begin{tabular}{|c|c|c|}
\hline No & $\begin{array}{c}\text { Desa } \\
\text { Pengusul }\end{array}$ & Usulan Program \\
\hline & & $\begin{array}{ll}\text { c. Paving Stone di Desa } \\
\text { Dharma Camplong } \\
\text { d. Pembangunan jalan } \\
\text { makadam Desa Dharma } \\
\text { Camplong } \\
\text { e. Perbaikan Drainase di } \\
\text { Dusun Pesisir Desa } \\
\text { Dharma Camplong } \\
\text { f. Pembangunan MCK } \\
\text { g. Perbaikan } \\
\text { Musholla/Masjid dan } \\
\text { Madrasah di Desa } \\
\text { Dharma Camplong }\end{array}$ \\
\hline
\end{tabular}

\section{KESIMPULAN}

Berdasarkan hasil pemetaan social di tiga lokasi desa yaitu Desa Tambaan, Banjar Talela dan Dharma Camplong terlihat bahwa antusiasme warga akan program CSR oleh PT Pertamina TBBM Camplong cukup tinggi. Hal ini terlihat dari jumlah dan variasi usulan dari warga masyarakat yang bereneka ragam. Meskipun program CSR merupakan salah satu bentuk kewajiban perusahaan, namun jumlah program dan besarnya dana yang digunakan tergantung dari alokasi dari perusahaan. Oleh karena itu perlu dibuat sebuah rencana program yang dapat berguna bagi pelaksanaan CSR pada masa yang akan datang.

\section{DAFTAR PUSTAKA}

Chambers, R. 1994. The Origins and Practices of Participatory Rural Appraisal. World Development. Vol 22 No 7. 953-969 pp.

Creswell, J.W. 2002. Research Design : Qualitative, Quantitative and Mixed Method Aprroaches. Second Edition. SAGE Publication.

Sanoff, H. 2000. Community Participation Methods in Design and Planning. New York. John Wiley \& Sons, Ltd.

Soekanto, S. 2007. Sosiologi Suatu Pengantar. Jakarta. Raja Grafindo.

Suharto, E. 2012. Metode dan Teknik Pemetaan Sosial. Tersedia On-IIne. http://www.policy.hu/Suharto/modul 18.htm.edi. 